\title{
DZIAŁANIA PODNOSZĄCE POZIOM KAPITAŁU LUDZKIEGO W NOWEJ PERSPEKTYWIE FINANSOWANIA 2014-2020
}

\begin{abstract}
Streszczenie
Kapitał ludzki stanowi podstawę rozwoju całych gospodarek i poszczególnych przedsiębiorstw. Jego poziom może rzutować między innymi na innowacyjność i konkurencyjność podmiotów gospodarczych. Dlatego tak ważne jest wspieranie jego rozwoju na każdym szczeblu, tzn. na szczeblu: jednostki ludzkiej, organizacji, jak i całego społeczeństwa. W tym obszarze duże znaczenie mają fundusze unijne, dzięki którym od lat są finansowane działania z zakresu podnoszenia poziomu kapitału ludzkiego. Nowa perspektywa finansowania 2014-2020 również przewiduje koncentrację na tym zagadnieniu. W artykule przedstawiono podstawowe informacje o kapitale ludzkim oraz miejsce działań nakierowanych na kapitał ludzki w nowej, unijnej perspektywie.
\end{abstract}

Słowa kluczowe: kapitał ludzki, perspektywa finansowania 2014-2020

\section{ACTIONS TO IMPROVE QUALITY OF HUMAN CAPITAL IN NEW FINANCIAL PERSPECTIVE 2014-2020}

\begin{abstract}
Summary
Human capital is the foundation of development, both for national economies and specific businesses. It can affect innovativeness and competitiveness of all entities. That is why it is so vital to support its development on every level. The European Union funds play a considerable role in this regard - thanks to them, numerous human capital development activities have been possible. The new financial perspective 2014-2020 is also going to focus on the issue of human capital. The paper presents basic information about human capital and the significance of the activities concerning human capital in the new European budget.
\end{abstract}

Key words: human capital, new financial perspective 2014-2020

\section{Wstęp}

Obecnie przedsiębiorstwa nie mogą przetrwać i rozwijać się bez odpowiednich pracowników. To umiejętności, kwalifikacje, potencjał zatrudnionych gwarantują firmie sukces (rozumiany jako przetrwanie i rozwój firmy w długim okresie). Stąd tak dużą rolę

${ }^{1}$ Dr hab. Urszula Gołaszewska-Kaczan - Wydział Zarządzania, Uniwersytet w Białymstoku; e-mail: ulakaczan@o2.pl. 
we współczesnej gospodarce przypisuje się kapitałowi ludzkiemu. Kapitał ludzki nie tylko warunkuje poziom innowacyjności gospodarki i całego społeczeństwa, zdolność przyswajania i wdrażania światowych osiagnięć, ale także umożliwia: unowocześnianie różnego rodzaju struktur, przemiany instytucjonalne, kształtowanie nowoczesnej infrastruktury różnego typu oraz propagowanie i upowszechnianie nowoczesnych wzorców konsumpcji i jakości życia [Makowski, 2000, s. 11]. Znaczenie kapitału ludzkiego wymusza na rządach państw, poszczególnych organizacjach oraz pojedynczych jednostkach konieczność inwestowania w ten kapitał.

W propagowaniu koncepcji praktycznego inwestowania w kapitał ludzki szczególną rolę odgrywa Unia Europejska ze swoimi programami finansowania określonych działań.

Celem niniejszego opracowania jest zarówno przybliżenie istoty kapitału ludzkiego, jak i odpowiedź na pytanie - czy w nowej perspektywie finansowania unijnego 2014-2020 jest możliwe wsparcie z funduszy unijnych działań z zakresu podnoszenia poziomu tego kapitału. W opracowaniu wykorzystano dostępną literaturę przedmiotu i materiały internetowe dotyczące nowej perspektywy finansowania.

\section{Kapitał ludzki i inwestycje w ten kapitał}

Termin kapitał ludzki jest pojęciem stosunkowo nowym. Wprowadzenie tego pojęcia miało na celu odróżnienie zasobowego podejścia do pracownika traktowanego w ramach zarządzania zasobami ludzkimi właśnie jako zasób, który jest kategorią statyczną i zależną od używanych wobec niego narzędzi, od podejścia nowego, kapitałowego - gdy pracownika w ujęciu kapitałowym uważa się za dźwignię zysku [Hydzik, Lewicka, 2012, s. 37].

Chcąc zdefiniować kapitał ludzki, należy uwzględnić fakt, iż pojęcie to może być rozpatrywane na różnych poziomach oraz w rozmaitych ujęciach. Przy definiowaniu kapitału ludzkiego trzeba przede wszystkim wziąć pod uwagę poziom rozważań. Kapitał ludzki na poziomie jednostki, jak stwierdza S. Domański, jest to: zasób wiedzy, umiejętności, zdrowia, siły i energii witalnej zawartej w człowieku. To uwarunkowany genetycznie potencjał, który można powiększać dzięki inwestycji w człowieka [Domański, 1993, s. 95]. Kapitał ludzki jest przypisany do danej osoby, jest dla niej specyficzny, zawsze jej towarzyszy.

Z kolei na poziomie firmy, według A. Sajkiewicz, kapitałem ludzkim są ludzie trwale związani z firma, jej misją, którzy charakteryzują się: umiejętnością współpracy, kreatywnością postaw i kwalifikacjami. Ludzie, bez których niemożliwy jest dalszy rozwój firmy [Sajkiewicz, 1999, s. 79]. Kapitał ten jest źródłem przyszłych dochodów zarówno dla pracownika - właściciela kapitału ludzkiego, jak i dla organizacji korzystającej z tegoż kapitału na określonych warunkach [Najlepsze praktykei zarzadzania zasobami ludžkimi, 2003, s. 44]. Warto zauważyć, że tracąc pracownika, przedsiębiorstwo traci także kapitał ludzki w nim zakumulowany, który, jak podkreślono wcześniej, jest charakterystyczny tylko dla danej osoby i nie ma możliwości jego skopiowania. 
Jeżeli rozpatruje się kapitał ludzki na poziomie gospodarki, to można wykorzystać definicję H. Króla i A. Ludwiczyńskiego, którzy stwierdzają że kapitał ludzki danego społeczeństwa - to zasób: wiedzy, umiejętności, zdrowia, energii witalnej zawarty w społeczeństwie, który może być źródłem sukcesu kraju, jego przewagi nad innymi [Zarzqdzanie zasobami ludzkimi. Tworzenie kapitatu ludzkiego onganizagi, 2006, s. 111].

Tymczasem definicje kapitału ludzkiego w różnych ujęciach, czyli pod względem cech, które ten kapitał obejmuje, uwzględniają dużą „pojemność” kapitału ludzkiego. Różni autorzy zaliczają bowiem do kapitału ludzkiego na przykład: wiedzę, umiejętności, kwalifikacje, stan zdrowia, prezentowaną aktywność społeczną i ekonomiczna, światopogląd oraz poziom kulturalny, praktykę zawodową, czynniki psychofizyczne, umiejętności fizyczne, energię witalną, a nawet urodę. Na tej podstawie często mówi się o węższym ujęciu kapitału ludzkiego, w którym za podstawową cechę przyjmuje się wiedzę nabytą w procesach kształcenia, oraz o ujęciach szerszych, w których podkreśla się znaczenie także innych cech kapitału ludzkiego budowanych równocześnie na bazie innych działań niż kształcenie. Zwrócenie uwagi na elementy kapitału ludzkiego jest niezbędne, zwłaszcza w perspektywie ewentualnego podwyższania poziomu kapitału ludzkiego przez odpowiednie inwestycje w ten kapitał. Różnorodność elementów (cech) kapitału ludzkiego pociaga za sobą również konieczność zróżnicowania obszarów inwestycji w ten kapital.

Rozważając kwestie związane z kapitałem ludzkim, należy wskazać dwa zjawiska specyficzne dla tego kapitału. Po pierwsze, ulega on zużyciu, co jest spowodowane kilkoma przyczynami. Z jednej strony deprecjacja kapitału ludzkiego jest skutkiem przeniesienia części jego wartości na efekt. $Z$ drugiej strony: $\mathrm{w}$ aspekcie biologicznym depregjacja przejania sie w:

- praejsciowej utracie zdolności do pracy (zmeczenie spowodowane nysitkiem fisycznym i psychicznym) lub

- creściowej lub catkowitej utracie zdolności do pracy (wskutek starzenia sie organizmu, wypadkón losowych, chorób itp.), Jamka, 2011, s. 145].

Natomiast zużycie „moralne” wiąze się z: postępem technicznym, nieustannymi zmianami, rozwojem wiedzy, ciagle nowymi wymaganiami, w wyniku czego posiadany przez człowieka kapitał jednocześnie dezaktualizuje się.

Drugim zjawiskiem związanym z kapitałem ludzkim - przeciwnym do poprzedniego - jest możliwość jego odnawiania, uaktualniania, a nawet podwyższania poziomu. Dokonuje się tego przez inwestycje w kapitał ludzki.

Inwestycje w kapitał ludzki to ogół działań, które wpływają na przyszły, pieniężny i fizyczny dochód dzięki powiększaniu zasobów w ludziach. Dotyczą one wszelkiej działalności oddziałującej na zmianę produkcyjności ludzi [Domański, 1993, s. 67]. Tak jak wiele cech (elementów) kapitału ludzkiego i wiele działań, które na te cechy mogą wpływać $i$ je rozwijać lub podnosić na wyższy poziom. W ramach często przytaczanej klasyfikacji inwestycji w kapitał ludzki wyróżnia się takie inwestycje, jak:

- $\quad$ wydatki na, szeroko rozumiane, usługi i udogodnienia związane z ochrona zdrowia wpływające na żywotność i witalność człowieka;

- $\quad$ wydatki na szkolenie w czasie pracy (na przyuczenie do zawodu i nabywanie praktyki w firmach); 
- $\quad$ wydatki na formalne kształcenie szkolne na wszystkich szczeblach (również dla osób dorosłych);

- $\quad$ wydatki na badania naukowe;

- $\quad$ wydatki związane z migracjami ludności w celu znalezienia lepszej pracy i możliwości zatrudnienia;

- $\quad$ wydatki na poszukiwanie informacji o sytuacji ekonomicznej firm i perspektywach zawodowych [Domański, 1993, s. 70].

Rozpatrując problem inwestycji w kapitał ludzki, należy podkreślić, że są to inwestycje „trudniejsze” od inwestycji w kapitał rzeczowy z kilku powodów. Po pierwsze, sa trudno mierzalne. Przy inwestycjach w kapitał ludzki niełatwo jest na przykład odróżnić wydatki o charakterze inwestycyjnym od wydatków o charakterze konsumpcyjnym. Również efekt tych inwestycji nie jest oczywisty i poddający się prostym opisom. Po drugie, inwestycje w kapitał ludzki należą do inwestycji kosztownych, a spodziewany wzrost poziomu kapitału ludzkiego następuje powoli i jest rezultatem wieloaspektowych dzialań społecznych. Przewidywane dochody, rozumiane jako zwrot $z$ tych inwestycji, trzeba rozpatrywać w perspektywie długookresowej [Korporowicz, 2005, s. 44].

Analizując inwestycje w kapitał ludzki warto zauważyć, iż będą one wymagały tym większych nakładów, im wyjściowy poziom kapitału danej osoby czy społeczeństwa jako całości jest niższy. Inne (poza poziomem wyjściowym) czynniki, które oddziałują na długość procesu inwestowania i ponoszone nakłady, to zdolność do przetworzenia dotychczasowego kapitału w nowy i stopa dyskontowa bądź stopa deprecjacji posiadanego kapitału [Czajka, 2011, s. 21].

Inwestycje w kapitał ludzki moga podejmować same jednostki, które widzą w tym szansę na lepsza pracę, większe dochody lub po prostu lepsze życie. Są to koszty związane na przykład z: edukacją, szkoleniami, nakładami na ochronę zdrowia, uczestnictwem w kulturze. Z kolei przedsiębiorstwa, dążące do zdobycia przewagi konkurencyjnej, inwestują w szkolenia, przekwalifikowania pracowników, wspomagają również podnoszenie poziomu ich zdrowia. Państwo, które chce zyskać innowacyjne, wykształcone, zdrowe, bogate społeczeństwo, finansuje rozwój oświaty, opieki zdrowotnej, kultury itp.

Jednocześnie podnoszenie poziomu kapitału ludzkiego stanowi ważny obszar zainteresowania Unii Europejskiej. Jednak oczywiste jest to, że poszczególne kraje unijne mają różny poziom kapitału ludzkiego. Jak zauważa Z. Czajka, różnic w poziomie kapitału ludzkiego w skali gospodarki pomiędzy tymi krajami nie można tłumaczyć różnicami w zdolnościach, inteligencji czy wrodzonych predyspozycjach narodów, lecz wynikają one $z$ różnic $w$ nakładach na tworzenie kapitału ludzkiego w danych państwach i z historycznych uwarunkowań [Czajka, 2011, s. 21]. Stąd nacisk Unii Europejskiej na działania związane nie tylko z podnoszeniem, ale także $z$ wyrównywaniem poziomu kapitału ludzkiego w krajach członkowskich i wspomaganie inicjatyw w tym zakresie funduszami unijnymi. Znajduje to swoje odbicie w założeniach nowej perspektywy finansowania na lata $2014-2020$. 


\section{Cele związane z podnoszeniem poziomu kapitału ludzkiego w nowej per- spektywie finansowania}

Fundusze unijne stanowią bardzo ważny czynnik wspomagający rozwój gospodarczy Polski. Wspierają one między innymi, wspomniane wcześniej, inwestycje w kapitał ludzki. Stąd tak ważne są założenia dotyczące nowej perspektywy finansowania na lata 2014-2020, które Parlament Europejski przyjął w formie pakietu rozporządzeń ustanawiających zasady programowania i funkcjonowania funduszy unijnych w okresie 2014-2020.

Nowe, wieloletnie ramy finansowania wiążą się z koniecznością wsparcia realizacji strategii „Europa 2020”. Strategia „Europa 2020”, przyjęta przez Radę Europejską w czerwcu 2010 roku, ma być odpowiedzią na słabości gospodarki europejskiej, które wyraźnie pokazał ostatni kryzys gospodarczy - zbyt niska stopa wzrostu i zbyt wysokie bezrobocie powoduja, że gospodarka europejska nie jest konkurencyjna w porównaniu z największymi partnerami gospodarczymi.

Strategia „Europa 2020” zakłada zdynamizowanie rozwoju całego ugrupowania, które ma być oparte na innowacjach. W związku z tym, celem sformułowanym w tej strategii jest rozwój: inteligentny, zrównoważony, sprzyjający włączeniu społecznemu. Rozwój inteligentny oznacza zwiększenie roli: wiedzy, innowacji, kształcenia i technologii cyfrowych. Z kolei rozwój zrównoważony łączy się z bardziej efektywnym wykorzystywaniem zasobów przy jednoczesnym zwiększeniu konkurencyjności. Natomiast rozwój sprzyjający włączeniu społecznemu koncentruje się na zwiększeniu aktywności zawodowej społeczeństw Unii Europejskiej, podnoszeniu kwalifikacji obywateli oraz walce z ubóstwem [Programowanie perspektymy finansowej 2014-2020 - uwarunkowania strategiczne, s. 5].

W strategii tej zakłada się więc realizację działań komplementarnych w trzech wymiarach: gospodarki opartej na wiedzy, wspierania gospodarki efektywniej korzystającej z zasobów (przez to bardziej konkurencyjnej) i przyjaznej środowisku, integracji społecznej, rozumianej jako wysoki poziom zatrudnienia, zapewniającej spójność społeczną i terytorialną [Świstak, 2014, s. 18].

Podstawowymi instrumentami realizacji celów strategii „Europa 2020” są przyjęte przez Komisję Europejską inicjatywy przewodnie:

- Unia innowacji - poprawa warunków ramowych do innowacji i wykorzystanie innowacji do rozwiązania najważniejszych problemów społecznych i gospodarczych, wskazanych w strategii „Europa 2020”;

- Mobilna mtodzież- poprawa jakości na wszystkich poziomach edukacji i szkoleń oraz zwiększanie atrakcyjności europejskiego szkolnictwa wyższego na arenie międzynarodowej;

- Europejska agenda cyfrowa - osiagnięcie trwałych korzyści gospodarczych i społecznych z jednolitego rynku cyfrowego, opartego na dostępie do szerokopasmowego Internetu;

- Europa efektywnie korzystajaca ₹ zasobón - wsparcie zmiany w kierunku gospodarki niskoemisyjnej i efektywniej korzystającej z zasobów środowiska, a także 
dążenie do wyeliminowania zależności wzrostu gospodarczego od degradacji środowiska przyrodniczego;

- Polityka przemystowa w erze globalizacji - poprawa warunków przedsiębiorczości, zwłaszcza MŚP, a także wsparcie rozwoju silnej bazy przemysłowej, zdolnej do konkurowania w skali globalnej;

- Program na rzecz nouych umiejetności i zatrudnienia - stworzenie warunków do unowocześnienia rynków pracy przez ułatwienie mobilności pracowników i rozwój ich umiejętności, w celu zwiększenia poziomu zatrudnienia i zapewnienie trwałości europejskich modeli społecznych;

- Europejski program walki z ubóstwem - zagwarantowanie spójności gospodarczej, społecznej i terytorialnej dzięki pomocy osobom biednym i wykluczonym, jak również umożliwieniu im aktywnego uczestniczenia w życiu ekonomicznym i społecznym [Strategia Europa 2020].

Już w strategii „Europa 2020” zwraca się uwagę na problem rozwoju kapitału ludzkiego, przede wszystkim w „Programie na rzecz nowych umiejętności i zatrudnienia", ale także w pozostałych inicjatywach.

Jak stwierdzono wcześniej, proces nowego programowania unijnego został podporządkowany celom strategii „Europa 2020”, która stanowi punkt odniesienia do wszystkich działań rozwojowych Unii Europejskiej współfinansowanych z unijnego budżetu wieloletniego 2014-2020.

Unia określiła w ramach nowego finansowania jedenaście celów tematycznych. $\mathrm{Na}$ poziomie poszczególnych funduszy cele tematyczne wiążą się z priorytetami inwestycyjnymi.

TABELA 1.

\section{Cele tematyczne i finansujące je fundusze}

\begin{tabular}{|c|c|}
\hline Cel tematyczny & Fundusz finansujący \\
\hline 1. Badania i działalność innowacyjna & EFRR, EFRROW, EFMR \\
\hline 2. Techniki informacyjno-komunikacyjne & EFRR, EFRROW \\
\hline $\begin{array}{l}\text { 3. Konkurencyjność MŚP sektora rolnego oraz sektora ry- } \\
\text { bołówstwa i akwakultury }\end{array}$ & EFRR, EFRROW, EFMR \\
\hline 4. Przejście na gospodarkę niskoemisyjną & EFRR, FS, EFRROW, EFMR \\
\hline $\begin{array}{l}\text { 5. Dostosowanie do zmian klimatycznych oraz zapobiega- } \\
\text { nie ryzyku i zarządzanie nim }\end{array}$ & EFRR, FS, EFRROW, EFMR \\
\hline $\begin{array}{l}\text { 6. Ochrona środowiska i efektywne wykorzystywanie zaso- } \\
\text { bów }\end{array}$ & EFRR, FS, EFRROW, EFMR \\
\hline $\begin{array}{l}\text { 7. Zrównoważony transport i usuwanie waskich gardeł w klu- } \\
\text { czowych infrastrukturach sieciowych }\end{array}$ & EFRR, FS, \\
\hline $\begin{array}{l}\text { 8. Promowanie zatrudnienia i wspieranie mobilności siły robo- } \\
\text { czej }\end{array}$ & $\begin{array}{l}\text { EFRR, EFS, EFRROW, } \\
\text { EFMR }\end{array}$ \\
\hline 9. Integracja społeczna i zwalczanie ubóstwa & $\begin{array}{l}\text { EFRR, EFS, EFRROW, } \\
\text { EFMR }\end{array}$ \\
\hline $\begin{array}{l}\text { 10. Edukacja, poszerzanie umiejętności i ustawiczne kształ- } \\
\text { cenie }\end{array}$ & $\begin{array}{l}\text { EFRR, EFS, EFRROW, } \\
\text { EFMR }\end{array}$ \\
\hline $\begin{array}{l}\text { 11. Kreowanie możliwości instytucjonalnych oraz efektywna } \\
\text { administracja publiczna }\end{array}$ & EFRR, EFS, FS \\
\hline
\end{tabular}

Źródło: [Świstak, 2014, s. 20]. 
Jak widać na podstawie powyższej tabeli, znaczna część celów to te, które są związane z ogólnie pojętym rozwojem kapitału ludzkiego. Cel 8. dotyczy: stworzenia nowych miejsc pracy, alternatywnych form zatrudnienia, podnoszenia kompetencji i kwalifikacji w wyniku realizacji szkoleń, zwłaszcza specjalistycznych, jak również działań łączących się z ochroną zdrowia. Cel 10. jest skierowany zarówno w stronę działań na poziomie wczesnoedukacyjnym, jak i późniejszym, a także działań na rzecz nabywania kompetencji i umiejętności stanowiących element zwiększający: szanse dopasowania się do zmiennych uwarunkowań i technologii, wsparcie kształcenia kompetencji i podnoszenia kwalifikacji oraz promowanie edukacji technicznej i zawodowej. Z kolei cel 9. obejmuje tworzenie i rozbudowę infrastruktury wsparcia dla rozwoju ekonomii społecznej i edukacji otoczenia przedsiębiorstw społecznych, co pozwoli na zaktywizowanie osób trwale bezrobotnych, rodzin wielodzietnych i osób niepełnosprawnych, zagrożonych wykluczeniem społecznym [Łepkowski, 2012, s. 8].

Realizacja powyższych celów powinna przyczynić się do podniesienia poziomu kapitału ludzkiego, rozpatrywanego zarazem w ujęciu szerszym, jak i szczególnie - w ujęciu węższym.

Należy także zwrócić uwagę, iż dla większości tych celów tych jest przewidywany wzrost finansowania, co świadczy o znaczeniu, jakie Unia Europejska przypisuje tym kierunkom rozwoju. Według zaproponowanej, wstępnej struktury udziału poszczególnych celów w całości alokacji dla Polski na lata 2014-2020 w porównaniu z taką samą struktura, ale dla okresu 2007-2013, można bowiem zaobserwować, że większe wsparcie nastąpi w obszarze kapitału ludzkiego (zatrudnienie, edukacja, włączenie społeczne).

TABELA 2.

Udział celów: 8., 9., 10. w alokacji, w latach 2014-2020

\begin{tabular}{|c|r|r|c|}
\hline Cele tematyczne & $\begin{array}{c}\text { Udział w alo- } \\
\text { kacji, w latach } \\
\mathbf{2 0 0 7 - 2 0 1 3} \\
\text { (w\%) }\end{array}$ & $\begin{array}{c}\text { Proponowany } \\
\text { udział w alokacji, } \\
\text { w latach 2014- } \\
\mathbf{- 2 0 2 0}(\mathbf{w} \%)\end{array}$ & Wzrost/spadek \\
\hline $\begin{array}{l}\text { Cel 8. Wspieranie zatrud- } \\
\text { nienia i mobilności pracow- } \\
\text { ników }\end{array}$ & 5,98 & $7-8$ & $\uparrow$ \\
\hline $\begin{array}{l}\text { Cel 9. Integracja społeczna } \\
\text { i zwalczanie ubóstwa }\end{array}$ & 4,35 & & $\uparrow, 4-5,6$ \\
\hline $\begin{array}{l}\text { Cel 10. Edukacja, poszerza- } \\
\text { nie umiejętności, uczenie się } \\
\text { przez całe życie }\end{array}$ & 8,18 & $6,2-8,2$ & $\uparrow \downarrow$ \\
\hline
\end{tabular}

Źródło: opracowanie własne na podstawie: [Łepkowski, 2012, s. 9].

Zostały wprowadzone istotne zmiany $\mathrm{w}$ zakresie ring fencingu na cele tematyczne: 8. - zatrudnienie, 9. - włączenie społeczne i 10. - edukacja.

Tak zwany ring fencing - wymóg przeznaczania określonych środków finansowych na poszczególne obszary tematyczne - jest powiązany z podstawowymi wskaźnikami strategii „Europa 2020”. Pułapy finansowe dotycza poszczególnych funduszy (EFRR, EFS). 
Ich wielkość najczęściej jest uzależniona od stopnia rozwoju poszczególnych regionów. Im lepiej rozwinięte regiony, tym pułapy wydatków ukierunkowanych na dany obszar tematyczny są wyższe. Oznacza to mniejszą elastyczność w podejmowaniu decyzji o wyborze obszarów wsparcia [Programowanie perspektymy finansowej 2014-2020 - uwarunkowania strategiczne, s. 8].

TABELA 3.

\section{Zestawienie ring fencingów}

\begin{tabular}{|c|c|c|c|c|c|}
\hline Obszar & $\begin{array}{c}\text { Rodzaj wskaźnika } \\
2020\end{array}$ & $\begin{array}{l}\text { Wartość dla } \\
\text { Unii } \\
\text { Europej- } \\
\text { skiej }\end{array}$ & $\begin{array}{c}\text { Wartość } \\
\text { dla Polski }\end{array}$ & $\begin{array}{l}\text { Cel tema- } \\
\text { tyczny }\end{array}$ & Ring fencing \\
\hline $\begin{array}{l}\text { Rozwój inteli- } \\
\text { gentny }\end{array}$ & $\begin{array}{l}\text { Wydatki na działaność } \\
\mathrm{B}+\mathrm{R}\end{array}$ & $3 \% \mathrm{PKB}$ & $1,7 \% \mathrm{PKB}$ & Cel 1. & \multirow{5}{*}{$\begin{array}{l}50-58 \% \text { środ- } \\
\text { ków EFRR, } \\
\text { z czego 6-20\% } \\
\text { na gospodarkę } \\
\text { niskoemisyjną }\end{array}$} \\
\hline \multicolumn{5}{|l|}{ Cel 3.} & \\
\hline \multirow[t]{3}{*}{$\begin{array}{l}\text { Rozwój zrów- } \\
\text { noważony }\end{array}$} & $\begin{array}{l}\text { Wzrost efektywności } \\
\text { energetycznej (zmniej- } \\
\text { szenie zużycia energii } \\
\text { pierwotnej do określo- } \\
\text { nego poziomu) }\end{array}$ & $20 \%$ & 96 Mtoe & \multirow[t]{3}{*}{ Cel 4.} & \\
\hline & $\begin{array}{l}\text { Udział energii ze źródeł } \\
\text { odnawialnych }\end{array}$ & $20 \%$ & $15 \%$ & & \\
\hline & Redukcja emisji $\mathrm{CO}_{2}$ & $20 \%$ & & & \\
\hline \multirow{5}{*}{$\begin{array}{l}\text { Rozwój sprzy- } \\
\text { jający włą- } \\
\text { czeniu spo- } \\
\text { łecznemu }\end{array}$} & $\begin{array}{l}\text { Stopa zatrudnienia (osoby } \\
\text { w wieku 20-64 lata) }\end{array}$ & $75 \%$ & $71 \%$ & Cel 8. & \multirow{5}{*}{$\begin{array}{l}25-50 \% \\
\text { środków PS } \\
\text { na EFS, z cze- } \\
\text { go } 20 \% \text { środ- } \\
\text { ków na ubós- } \\
\text { two }\end{array}$} \\
\hline & $\begin{array}{l}\text { Udział osób z wyższym } \\
\text { wykształceniem w spo- } \\
\text { łeczeństwie (osoby w wie- } \\
\text { ku 30-34 lata) }\end{array}$ & $40 \%$ & $45 \%$ & Cel 10. & \\
\hline & $\begin{array}{l}\text { Odsetek osób wcześnie } \\
\text { kończących naukę }\end{array}$ & $10 \%$ & $4,5 \%$ & & \\
\hline & \multicolumn{4}{|l|}{ Cel 11.} & \\
\hline & $\begin{array}{l}\text { Zmniejszenie liczby osób } \\
\text { zagrożonych ubóstwem }\end{array}$ & O $20 \mathrm{mln}$ & O $1,5 \mathrm{mln}$ & Cel 9. & \\
\hline $\begin{array}{l}\text { Terytorialny } \\
\text { wymiar inter- } \\
\text { wencji (miasta) }\end{array}$ & & & & & $\begin{array}{l}\text { 5\% środków } \\
\text { EFRR }\end{array}$ \\
\hline
\end{tabular}

Źródło: [Nowa perspektywa..., s. 5].

Jak widać w przypadku celów: 9. czy 10., zamierzenia w stosunku do Polski są większe niż w stosunku do Unii Europejskiej jako całości. Stąd pojawia się przed Polską większe wyzwanie. 


\section{Proponowane kierunki interwencji w ramach poszczególnych celów tema- tycznych, związanych z podnoszeniem poziomu kapitału ludzkiego}

Z podnoszeniem poziomu kapitału ludzkiego są związane przede wszystkim cele: 8. i 10., ale można także doszukiwać się powiązania z celem 9.

Cel 8., czyli wspieranie zatrudnienia i mobilności pracowników, przekłada się na cel szczegółowy, jakim jest efektywniejsze wykorzystanie zasobów na rynku pracy, a ten obejmuje:

- poprawę adaptacyjności osób aktywnych zawodowo i pracodawców;

- poprawę zdrowia zasobów pracy;

- zwiększenie zatrudnienia osób bezrobotnych i poszukujących pracy [Fundusze Europejskie 2014 -2020..., s. 25].

Sytuacja na polskim rynku pracy jest niekorzystna. Obserwuje się wysoką stopę bezrobocia - 13,5\% (marzec 2014 rok) i problemy młodych ludzi z wejściem na rynek pracy. W marcu 2014 roku osoby w wieku 18-24 lata stanowiły aż 17,5\% ogółu zarejestrowanych bezrobotnych. Nadal pozostaje wysoki poziom bezrobocia długotrwałego; ta grupa wynosiła 39,8\% ogółu zarejestrowanych bezrobotnych w końcu marca 2014 roku [Sytuacja na rynku pracy..., s. 2-3].

Jednocześnie problem stwarza wczesny wiek dezaktywacji zawodowej, zwłaszcza kobiet, oraz brak wykształcenia (postrzegany głównie wśród osób starszych) bądź jego niedostosowanie do potrzeb współczesnego rynku pracy. Jak zauważa się: Udriat młodziešy w zatrudnieniu jest nižssy niz przecietna w Unii Europejskiej, zaś besrobocie w tej grupie

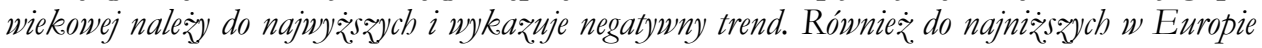

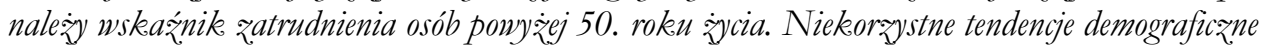
- niewielki prayrost naturalny oraz proces starzenia sie spoleczeństwa spowoduja kurczenie sie zasobów pracy. Stopniowo eliminowane beda rozwiazania systemu emerytalno-rentowego, które pozwalaja na wcresna dezaktywacje, priy jednoczesnym podnoszeniu wieku emerytalnego [Programowanie perspek.tywy finansowej 2014-2020 - uwarunkowania strategiczne, s. 17].

Stąd interwencja na poziomie krajowym powinna obejmować wspieranie przygotowania i przeprowadzenia reform w obszarze zatrudnienia, np. poprawianie efektywności usług świadczonych na rzecz klientów instytucji rynku pracy czy modernizacja systemu zarządzania informacjami wykorzystywanymi w usługach rynku pracy. Z kolei na poziomie regionalnym wsparcie powinno być kierowane do poszczególnych osób w celu poprawy ich sytuacji na rynku pracy. Działania takie mogą służyć: podnoszeniu kwalifikacji, wspieraniu przedsiębiorczości, samozatrudnieniu, rozwijaniu zdolności przystosowania się przedsiębiorstw i pracowników do zmian [Projekt linii..., s. 19].

Obszarem, na który należy zwrócić uwagę, jest rozwój i upowszechnianie elastycznych form zatrudnienia i organizacji pracy. Elastyczność zatrudnienia i organizacji pracy stanowi element elastycznego rynku pracy, który można zdefiniować jako zdolność tego rynku do przystosowywania się do dynamicznie zmieniających się warunków, jak również umiejętność adaptacji do pojawiających się, nowych rozwiązań technologicznych [Kalinowska i inni, 2001 s. 8]. Rozwiazzania te wspomagają zarówno grupy będące w najtrudniejszej sytuacji na rynku pracy, dając im szansę na podjęcie zatrudnienia, jak i przedsiębiorców, pozwalając im dostosowywać się do zmieniającej się koniunktury na rynku. 
Dzieje się tak dzięki takim cechom elastycznego zatrudnienia, jak m.in: dowolna forma umowy, dopasowany do sytuacji wymiar czasu pracy oraz miejsce wykonywania pracy, dowolna regularność wykonywania pracy.

W cel 8. wpisują się także inne działania pozwalające na adaptację pracowników i przedsiębiorców do zmian w otoczeniu gospodarczym. Jak stwierdza się: Dứa podaż szkolen ogólnych $i$ niski pozrom ksztatcenia nie przekłada sie na podnoszenie adaptacyjności pracownikón $i$ konkurencyjność gospodarki. $Z$ drugiej strony sžkolenia specjalistyczne, majace wartość edukacyjna, charakteryzuja sie inwestowaniem przezp przedsiebiorców w rozwijanie tych kompetencii swoich pracowników, które maja specyficzny charakter - daja sie wykorzystać przede wsaystkim w danej firmie/przedsiebiorstwie [Programowanie perspektyny finansowej 2014-2020 - uwarunkowania strategiczne, s. 17].

Konieczne staje się stworzenie szerszych możliwości związanych z samodzielnym nabywaniem i podwyższaniem kwalifikacji przez pracowników z pominięciem pracodawcy. Ta indywidualizacja szkoleń powinna być poprzedzona prawidłowym rozpoznaniem potrzeb szkoleniowych, zarówno z punktu widzenia pojedynczego pracownika, jak i organizacji. Dopasowanie szkoleń (problematyki, wykorzystywanych technik i metod, czasu trwania itp.) do zapotrzebowania jest więc wyzwaniem w nowej perspektywie finansowania.

W ramach celu 8. kolejne działania powinny dotyczyć wzmocnienia instytucji rynku pracy przez zmianę modelu działania publicznych służb zatrudnienia (oddzielenie usług aktywizacyjnych od czysto administracyjnych, opracowanie i wdrożenie systemu kontraktacji usług aktywizacyjnych poza publiczne służby zatrudnienia). Konieczne będzie zsynchronizowanie działalności publicznych służb zatrudnienia i służb pomocy społecznej.

W celu 8. zwraca się również uwagę na ochronę zdrowia. Jak zauważa się: Wsparcie koncentrować sie bedzie na uysokospegjalistycznej infrastrukturze ochrony zdrowia - projekty praycryniajace sie do zapewnienia udzielania specjalistycznych i wysokospecjalistycznych swiadcren zdrowotnych, inwestyge w zakeresie zintegrowanego systemu ratownictwa medycznego, prowadzenie driatalności dydaktycrnej $i$ badawczej w driedzinie nauk medycznych oraz, wprowadzanie nowoczesnych rozwiazan w praktyke [Programowanie perspektywy finansowej 2014-2020 - uwarunkowania strategiczne, s. 17].

Drugim celem, ściśle związanym z podwyższaniem poziomu kapitału ludzkiego, jest cel 10. Cel ten, czyli inwestowanie w edukację, umiejętności i uczenie się przez całe życie, przekłada się na cel szczegółowy, jakim są lepsze kompetencje kadr gospodarki, a obejmuje:

- $\quad$ poprawę jakości kształcenia na wszystkich etapach edukacji;

- lepszy dostęp do wysokiej jakości i stabilnych usług edukacyjnych;

- zwiększenie powiązania systemu edukacji i umiejętności osób z potrzebami rynku pracy [Fundusze Europejskie 2014 -2020..., s. 31]

Jak stwierdzono wcześniej, to właśnie inwestycje w edukację na każdym poziomie sa podstawowymi inwestycjami w kapitał ludzki.

$\mathrm{Z}$ poziomu krajowego finansowanie będzie skierowane $\mathrm{w}$ stronę wspierania przygotowania i przeprowadzenia reform w obszarze, szeroko pojętej, edukacji. $\mathrm{Na}$ tym także poziomie będą realizowane z EFS działania na rzecz szkolnictwa wyższego. Z kolei na poziomie regionalnym inwestycje powinny dotyczyć indywidualnych osób uczestni- 
czących w procesie kształcenia przez całe życie. Na tym poziomie będzie również wspierana infrastruktura edukacyjna i szkoleniowa - wsparcie szkół zawodowych wynikające $z$ inteligentnych specjalizacji danego regionu; infrastruktura związana z prowadzeniem kształcenia ustawicznego w formach pozaszkolnych; infrastruktura przedszkolna [Projekt linii..., s. 27].

Podejmowane działania będą łączyć się z rozwojem zarówno opieki nad najmłodszymi, jak i edukacji od najmłodszych lat. Duże znaczenie przypisuje się działaniom na rzecz nabywania kompetencji i umiejętności jako elementów zwiększających szanse dopasowania się do zmiennych uwarunkowań i technologii. Zwrócona zostanie uwaga na podnoszenie kwalifikacji i umiejętności kadry - wprowadzenie modelu kształcenia kadry akcentującego: pracę zespołową, wykorzystanie nowoczesnych technologii, kształcenie kompetencji i kwalifikacji. Priorytetem będzie również rozwój szkolnictwa wyższego odpowiadającego na potrzeby innowacyjnej gospodarki i regionalnych rynków pracy. Znaczącą rolę będzie odgrywało wykorzystanie technologii informacyjnych w poszczególnych dziedzinach aktywności (m.in.: e-edukacja, e-zdrowie, ekultura, e-integracja) oraz działania na rzecz rozwoju kompetencji cyfrowych [Programowanie perspektyny finansowej 2014-2020 - uwarunkowania strategiczne, s. 17-18].

Jak widać, powyższe działania maja służyć zdobywaniu wiedzy. Jednak należy zwrócić uwagę na fakt, iż wiedza to nie to samo co informacja. Wiedza to przetransponowana informacja, to informacja, która jesteśmy w stanie wykorzystać, przekazać. Stąd konieczność położenia nacisku nie tylko na zdobywanie informacji, ale właśnie na zdobywanie kompetencji, umiejętności, czyli zdobywanie wiedzy. W nowej gospodarce bowiem:

- $\quad$ wiedza zastępuje pracę i kapitał jako podstawowe źródło tworzenia wartości;

- $\quad$ udział zawartości wiedzy w produktach i usługach szybko rośnie;

- $\quad$ wiedza stale zmienia się;

- $\quad$ wiedza staje się szczególnie ważna w sektorze wysokowartościowych usług;

- $\quad$ ekonomika dla aktywów niematerialnych działa inaczej niż ma to miejsce w przypadku aktywów materialnych;

- $\quad$ w nowej ekonomii zmienia się pojęcie własności i kontroli nad zasobami;

- zmienia się podejście do zagadnienia konkurowania;

- przeobrażeniu ulegają same organizacje;

- w nowej ekonomii zmienia się charakter pracy [Urbanek, 2007, s. 19-22].

Cel 9. nie jest bezpośrednio związany z podwyższaniem poziomu kapitału ludzkiego, jednakże w sposób pośredni przekłada się na jego poziom przy szerokim podejściu do istoty kapitału ludzkiego.

Cel 9., czyli wspieranie włączenia społecznego i walka z ubóstwem, oddziałuje na cel szczegółowy, jakim jest zmniejszenie poziomu ubóstwa i obejmuje:

- poprawę szans na włączenie społeczne/integrację społeczną osób znajdujacych się w szczególnie trudnej sytuacji życiowej;

- kompleksową rewitalizację;

- $\quad$ poprawę dostępu do wysokiej jakości usług społecznych [Programowanie perspektywy finansowej 2014-2020]. 
Jak stwierdza się: Na poziomie krajonym interwencja będzie sie koncentrować na wspieraniu priygotowania i przeprowadzenia reform w obszarze wtaczenia spotecznego. Na tym poziomie realizowane beda rómnież driatania na rzecz, uysokospecjalistycznej opieki zdrowotnej (jednostki chorobowe majace najwiekszy wplyw na ak.tywnosí zawodowa) oraz zwiazane z ratownictwem medycznym. $\mathrm{Na}$ poziomie regionalmym wsparcie powinno obejmować zapewnienie ustug indynidualnym osobom majacych na celu przeciwdziatanie uykluczeniu spotecznemu. $Z$ tego poziomu realizowane beda również interwencje zwiqzane z. ochrona zdrowia $i$ infrastruktura spoteczna, uyrównujace nierówności w dostepie do ustug na poziomie regionalnym i lokalnym. Wspierana bedrie rewitalizacja w oparciu o LPR, taczaca trow. driatania miekkkie z. inwestycjami infrastrukturalnymi [Projekt linii..., s. 23].

Działania w tym zakresie będa dotyczyć przede wszystkim: osób trwale bezrobotnych, rodzin wielodzietnych, osób niepełnosprawnych, ale także tzw. biednych pracujących. Likwidowanie deficytów tych jednostek, wspieranie ich potencjałów i zwiększenie dostępu do rehabilitacji przyczynią się do podwyższenia poziomu kapitału ludzkiego właśnie w sposób pośredni.

Podobnie wsparcie podmiotów ekonomii społecznej, obejmujące zarówno przyznawanie dotacji, jak i ułatwienie dostępu do usług finansowych dla podmiotów ekonomii społecznej, w szczególności do zwrotnych instrumentów finansowych, pozwoli na rozwój tych podmiotów. Rozszerzenie działań na rzecz tworzenia i rozbudowy infrastruktury wsparcia dla rozwoju ekonomii społecznej (wsparcie dla szeroko rozumianych instytucji otoczenia ekonomii społecznej, np. stowarzyszeń przedsiębiorców społecznych i centrów transferu wiedzy itp.) oraz edukacji otoczenia przedsiębiorstw społecznych (zwłaszcza administracji lokalnej, m.in. jako istotnego zleceniodawcy dla przedsiębiorstw społecznych) ma równocześnie posłużyć realizacji celu 9. Jednocześnie zakłada się tutaj realizację programów sprzyjających aktywizacji lokalnych społeczności, w tym przede wszystkim społeczności marginalizowanych. Tego rodzaju działania przyczyniają się do budowy kapitału społecznego. W tym obszarze ważne są także działania na rzecz zwiększenia dostępności do usług ochrony zdrowia oraz usług społecznych [Programowanie perspektywy finansowej 2014-2020 - uwarunkowania strategiczne, s. 17-18].

\section{Podsumowanie}

Znaczenie kapitału ludzkiego na różnych poziomach gospodarowania sprawia, że inwestycje w ten kapitał są konieczne. Jednak inwestycje te są bardzo kosztowne, więc zarówno jednostki, organizacje, jak i rządy poszczególnych państw szukają wsparcia w tym zakresie, między innymi wykorzystując fundusze unijne.

Analiza informacji przedstawionych w artykule pozwala pozytywnie odpowiedzieć na pytanie postawione na wstępie opracowania. W nowej, unijnej perspektywie finansowania cele związane z podnoszeniem poziomu kapitału ludzkiego znalazły swoje miejsce, lecz w dokumentach unijnych zwraca się większą uwagę na wybór obszarów wsparcia i odbiorców działań, tak aby zrealizować wskaźniki wyznaczone w planach. 


\section{Literatura}

Czajka Z. 2011 Gospodarowanie kapitatem lud₹kim, Wydawnictwo Uniwersytetu w Białymstoku, Białystok.

Dokument elektroniczny, tryb dostępu: [http://www.funduszeeuropejskie.gov.pl/ 2014_2020/Strony/Przebieg_negocjacji_nad_ksztaltem_polityki_spojnosci_po_ 2013_czerwiec_2012.aspx?N=N, data wejścia: 17.07.2014].

Domański S. 1993 Kapitał ludzki i wrost gospodarczy, PWN, Warszawa.

Fundusze Europejskie 2014-2020 - Cele Umony Partnerstwa i zatożenia Programów Operacyjnych, dokument elektroniczny, tryb dostępu: [http://www.fundusze.malopolska.pl/ 2014_2020/Lists/Szkolenia/Attachments/235/Cele-tematyczne-oraz-zakresinterwencji-na-poziomie-krajowym-okreslone-umowa-partnerstwa.pdf, data wejścia: 17.07.2014].

Hydzik W., Lewicka D. 2012 Zarzadzanie kapitatem ludzkim w organizacji z uykorsystaniem metody analizy sieci spotecznych (social network analysis), [w:] Sukces w zarzadzaniu kadrami. Elastycznośc w zarzadzaniu kapitatem ludzkim, T. Listwan, M. Stor (red.), Wydawnictwo Uniwersytetu Ekonomicznego we Wrocławiu, Wrocław.

Jamka B. 2011 Caynnik ludzki we wspótczesnym præ̌edsiębiorstwie: zasób cayy kapitał?, Oficyna a Wolters Kluwer Business, Warszawa.

Kalinowska I., Kujszczyk B., Mańturz M., Sojko J., Świercz B., Tymonuk A. 2001 Informator - elastyczne formy zatrudnienia, Wydawnictwo WU-PwW, Warszawa.

Korporowicz V. 2005 Zdrowie i jego promocja. Ksztaltowanie przysztości, OW SGH w Warszawie, Warszawa.

Lepkowski M. 2012 Nowe możliwości wykkoryystania fundus zy europejskich w swietle perspektywy finansowania 2014-2020, „Biuletyn Informacyjny ITS”, nr 6.

Makowski K. 2000 Kapitat ludæzki w skali mikroekonomicznej, Monografie i Opracowania SGH, nr 470.

Najlepsze praktyki zarzadzania zasobami ludžkimi 2003, A. Pocztowski (red.), Oficyna Ekonomiczna, Kraków.

Nowa perspektywa programowo-finansowa UE - 2014-2020 - najwaizniejsze zmiany, CDR w Brwinowie, Kraków 2013, dokument elektroniczny, tryb dostępu: [http://cdrkursy.edu.pl/ cdr/wydawnictwa/perspektywa2020.pdf, data wejścia: 16.07.2014].

Programowanie perspektyny finansowej 2014-2020 - uwarunkowania strategiczne, Departament Koordynacji Polityki Strukturalnej, dokument elektroniczny, tryb dostępu: [https://www.mir.gov.pl/fundusze/Fundusze_Europejskie_2014_2020/Progra mowanie_2014_2020/Documents/uwarunkowania_strategiczne.pdf, data wejścia: 15.07.2014].

Programowanie perspektywy finansowej 2014-2020, dokument elektroniczny, tryb dostępu: [http://www.umwd.dolnyslask.pl/fileadmin/user_upload/pife/Programowanie_ perspektywy_finansowej_2014-2020.pdf, data wejścia: 16.07.2014].

Projekt linii demarkacyjnej 2014-2020 (czerviec 2013 rok), dokument elektroniczny, tryb dostępu: [www.rpo.podkarpackie.pl/, data wejścia: 16.07.2014].

Sajkiewicz A. 1999 Cz̨towiek - kreator wartości przedsiebiorstwa, [w:] Zarzadzanie wartościa przedsiebiorstwa, A. Herman, A. Szablewski (red.), POLTEXT, Warszawa. 
Strategia Europa 2020, dokument elektroniczny, tryb dostępu: [http://www.mg.gov.pl/ Bezpieczenstwo+gospodarcze/Strategia+Europa+2020, data wejścia: 15.07.2014].

Sytuacja na rynku pracy w Polsce, dokument elektroniczny, tryb dostępu: [http://www.psz. praca.gov.pl $/$ main.php?do $=$ ShowPage\&nPID $=867738 \& \mathrm{pT}=$ details\&sP $=$ CONT ENT,objectID,868123, data wejścia: 20.07.2014].

Świstak M. 2014 Fundusze unijne na lata 2014-2020. Programowanie na poziomie unijnym i krajonym, „Unia Europejska.pl”, nr 1.

Urbanek G. 2007 Pomiar kapitatu intelektualnego i aktywów niematerialnych przedsiebiorstwa, Wydawnictwo Uniwersytetu Lódzkiego, Łódź.

Zarz̨qdzanie zasobami ludzkimi. Tworzenie kapitatu ludzkiego organizacji 2006, H. Król, A. Ludwiczyński (red.), PWN, Warszawa. 